\title{
Studi Eksperimental Pengaruh Sudut Kemiringan Penyambungan Balok Beton dengan Bondcrete Terhadap Kuat Lentur Beton
}

\author{
Andre Feliks Setiawan*1, Dafit Natalius ${ }^{2}$, Josephine Karmela ${ }^{3}$ \\ ${ }^{1,3}$ Program Studi Manajemen Rekayasa dan Konstruksi, Universitas Agung Podomoro, Indonesia \\ ${ }^{2}$ PT Astra Honda Motor, Indonesia \\ E-mail: ${ }^{1 *}$ andre.feliks@ podomorouniversity.ac.id
}

Received 08 March 2021; Reviewed 17 March 2021; Accepted 07 April 2021

Journal Homepage: http://jurnal.borneo.ac.id/index.php/borneoengineering

\begin{abstract}
Concrete is a structural material that is widely used and utilized in the construction industry. In the implementation of concrete casting in the field, there are times when it has to be delayed in the middle of casting either due to unfavorable weather, cessation of delivery of ready-mix concrete, or due to the problems with the casting supporting tools, so casting work must be carried out gradually. Therefore, this research was carried out to analyze the strength of the old concrete connection with new concrete. The purpose of this study was to determine the effect of the age of the concrete at the time of joining using bondcrete on the flexural strength of the concrete with f'c $=25 \mathrm{MPa}$, and to determine the effect of the angle of the joints on the concrete to be joined. From this research, it can be neglected that the increasing age of the old concrete when grafting will result in a smaller value for the flexural strength of the concrete. Concrete that is joined at a $45^{\circ}$ inclination angle produces a higher flexural strength value than concrete joined at a $60^{\circ}$ inclination angle. Besides, the use of bondcrete can increase the flexural strength of the joined concrete blocks by $15.572 \%$.
\end{abstract}

Keywords: concrete beam; flexural strength; bondcrete

\begin{abstract}
Abstrak
Beton adalah salah satu bahan struktur yang banyak dipakai dan dimanfaatkan dalam industri konstruksi. Dalam pelaksanaan pengecoran beton di lapangan, ada kalanya tertunda ditengahtengah pengecoran baik karena cuaca yang tidak mendukung, terhentinya pengiriman beton ready mix, maupun karena masalah rusaknya alat-alat penunjang pengecoran, sehingga pengerjaan pengecoran harus dilakukan secara bertahap. Untuk itu dilakukan penelitian mengenai kekuatan sambungan beton lama dengan beton baru. Tujuan penelitian ini adalah untuk mengetahui pengaruh umur beton pada saat penyambungan dengan menggunakan bondcrete terhadap kuat lentur beton dengan $f^{\prime} c=25 \mathrm{Mpa}$, dan untuk mengetahui pengaruh sudut kemiringan sambungan pada beton yang akan disambung. Dari penelitian ini dapat disimpulkan bahwa semakin bertambahnya umur beton lama saat penyambungan akan menghasilkan nilai kuat lentur beton yang semakin kecil. Beton yang disambung dengan sudut kemiringan penyambungan $45^{\circ}$ menghasilkan nilai kuat lentur yang lebih besar daripada beton yang disambung dengan sudut kemiringan penyambungan $60^{\circ}$. Selain itu penggunaan bondcrete dapat menambah kekuatan lentur balok beton yang disambung sebesar 15,572\%.
\end{abstract}

Kata kunci: balok beton; kuat lentur; bondcrete 


\section{Pendahuluan}

Beton adalah salah satu bahan struktur yang banyak dipakai dan dimanfaatkan dalam pekerjaan bangunan. Selain beton masih ada juga material-material lain yang dapat digunakan untuk struktur bangunan seperti baja dan kayu. Penggunaan beton sebagai struktur utama bangunan lebih banyak keuntungannya dibandingkan dengan material lainnya. Keuntungan dari beton antara lain adalah beton mudah dibentuk, material pembentuknya mudah didapat, biaya pembuatan relatif murah, dan tidak memerlukan perawatan khusus, serta kekuatannya dapat diatur sesuai kebutuhan di lapangan (Hajek, 2017).

Struktur beton direncanakan sesuai dengan standar yang ada dan diharapkan dapat digunakan dalam kurun waktu yang cukup lama. Oleh karena itu dari segi perencanaan, perhitungan, sampai dengan pelaksanaan konstruksi di lapangan harus dilakukan dengan tepat dan benar, karena dapat merugikan dari segi biaya maupun faktor keselamatan. Untuk menghindari hal-hal yang tidak diinginkan, maka pengerjaan beton menjadi salah satu hal yang harus diperhatikan. Dalam pelaksanaan pengecoran beton di lapangan, ada kalanya tertunda ditengah-tengah pengecoran baik karena cuaca yang tidak mendukung, terhentinya pengiriman beton ready mix, maupun karena masalah rusaknya alat-alat penunjang pengecoran, sehingga pengerjaan pengecoran harus dilakukan secara bertahap. Selain itu adanya perubahan rencana, yang memerlukan suatu sambungan beton. Untuk itu dilakukan penelitian mengenai kekuatan sambungan beton lama dengan beton baru.

Penelitian terdahulu telah dilakukan oleh Septiawan (2014) dengan melakukan pengujian sambungan dengan letak yang bervariasi tanpa menggunakan bahan perekat, oleh karena itu dalam penelitian ini digunakan bahan perekat sebagai bahan tambahan penyambung beton lama dengan beton baru. Jenis bahan perekat yang digunakan adalah bondcrete. Bondcrete merupakan bahan perekat dan pengikat yang sangat fleksibel, digunakan secara luas dalam industri konstruksi dan renovasi. Beberapa kegunaan bondcrete yaitu untuk penambal, campuran cat, pemasangan keramik, campuran adukan, dan bahan pengikat (Zulkarnain, 2018). Sebelum pengecoran beton baru, permukaan beton lama dibersihkan dari kotoran-kotoran, dibuat kasar, lalu diberi bondcrete. Dalam pemakaiannya, bondcrete dicampur air dengan perbandingan tertentu lalu dioleskan pada beton lama sebelum dilakukan pengecoran beton baru. Dengan adanya bahan perekat ini diharapkan beton lama dan beton baru memiliki daya ikat yang lebih baik.

Tujuan dari penelitian ini adalah untuk mengetahui pengaruh umur beton pada saat penyambungan dengan menggunakan bondcrete terhadap kuat lentur beton dengan mutu beton ( $\left.\mathrm{f}^{\prime} \mathrm{c}\right)=25 \mathrm{MPa}$ dan untuk mengetahui pengaruh sudut kemiringan sambungan pada beton yang akan disambung terhadap kuat lentur beton. Hasil penelitian kuat lentur sambungan beton tersebut dibandingkan dengan kuat lentur beton tanpa sambungan dan dapat dilihat pada bagian Hasil dan Pembahasan.

\section{Metode \& Pelaksanaan Penelitian}

Metode dan pelaksanaan penelitian mengacu pada peraturan Standar Nasional Indonesia SNI 032834-2000 tentang Tata Cara Pembuatan Rencana Campuran Beton Normal. Rencana campuran beton yang dibuat dan diuji adalah beton dengan mutu f'c $=25 \mathrm{MPa}$. Pengujian kuat tekan dilakukan pada umur beton 7, 14, 21 dan 28 hari dengan masing-masing 3 buah benda uji berbentuk silinder dengan diameter $150 \mathrm{~mm}$ dan tinggi $300 \mathrm{~mm}$. Pengujian kuat lentur tanpa sambungan dilakukan pada hari ke-28 dengan masing-masing 3 buah benda uji berbentuk balok dengan ukuran 600x150x150 mm3. Untuk beton dengan sambungan uji kuat lentur dilakukan 28 hari setelah beton baru dicor. Pengecoran beton baru dilakukan pada beton lama yang berumur 14 dan 28 hari, dengan 3 buah benda uji untuk masing-masing umur beton lama. Sudut kemiringan sambungan dibuat dalam 2 jenis yaitu kemiringan $45^{\circ}$ dan $60^{\circ}$. Sebelum beton baru dicor, bagian 
dari beton lama dilapisi dengan bondcrete. Sebagai perbandingan, dibuat benda uji balok yang disambung tanpa dilapisi bondcrete.

\subsection{Pemeriksaan Agregat}

Langkah awal yang perlu dilakukan dalam merencanakan campuran beton (mix design) adalah melakukan pengujian atau pemeriksaan agregat (Tata Cara Pembuatan Rencana Campuran Beton Normal, 2000). Pemeriksaan agregat dimaksudkan untuk mendapatkan bahan-bahan campuran beton yang memenuhi syarat. Oleh karena itu, tidak setiap agregat dapat langsung digunakan begitu saja, perlu adanya kontrol atau pemeriksaan terhadap kualitas dari agregat yang akan digunakan sebagai bahan penyusun beton (Velay-Lizancos et al., 2018). Pemeriksaan agregat ini meliputi pemeriksaan kadar bahan orgaik, kadar air agregat, kadar silt dan clay, berat jenis dan absorpsi, analisis saringan, dan berat isi.

\subsection{Perencanaan Campuran Beton}

Setelah dilakukan pemeriksaan agregat langkah selanjutnya yang dilakukan adalah merencanakan campuran beton (Tata Cara Pembuatan Rencana Campuran Beton Normal, 2000). Perencanaan campuran beton dilakukan dengan mengacu kepada Standar Nasional Indonesia (SNI) 03-28342000 mengenai Tata Cara Pembuatan Rencana Campuran Beton Normal.

\subsection{Pengujian Beton Segar}

Setelah proses pencampuran beton selesai, maka diperlukan pengujian beton segar. Pengujian beton segar dilakukan untuk mengetahui kekentalan beton yang berpengaruh terhadap kemudahan pengerjaan (workability) dan homogenitas dari campuran beton (Nguyen et al., 2020). Pada penelitian ini dilakukan pengujian beton segar dengan slump test. Pada pengujian in, persyaratan nilai slump diambil sebesar 30-60 mm (Cara Uji Slump Beton, 2008).

\subsection{Pengujian Kuat Tekan Beton}

Pada penelitian ini, uji kuat tekan beton dilakukan untuk mengetahui apakah mutu beton yang direncanakan tercapai atau tidak. Uji kuat tekan beton dilakukan pada hari ke 7, 14, 21 dan 28 dengan masing-masing 3 buah benda uji seperti terlihat pada Tabel 1 .

Tabel 1. Data Hasil Uji Kuat Tekan Beton

\begin{tabular}{|c|c|c|c|c|}
\hline Umur Beton & $\begin{array}{c}\text { Berat Beton } \\
(\mathrm{kg})\end{array}$ & $\begin{array}{c}\text { Diameter rata- } \\
\text { rata }(\mathrm{mm})\end{array}$ & $\begin{array}{l}\text { Tinggi } \\
\text { (mm) }\end{array}$ & $\begin{array}{c}\text { Beban Hancur } \\
(\mathbf{k N})\end{array}$ \\
\hline \multirow{3}{*}{7 hari } & 12,03 & 150,0 & 301,0 & 270 \\
\hline & 11,98 & 150,0 & 301,0 & 260 \\
\hline & 12,11 & 149,3 & 301,0 & 275 \\
\hline \multirow{3}{*}{14 hari } & 11,82 & 149,0 & 301,0 & 390 \\
\hline & 12,02 & 148,7 & 301,3 & 372 \\
\hline & 12,25 & 149,0 & 301,0 & 370 \\
\hline \multirow{3}{*}{21 hari } & 12,21 & 150,0 & 300,7 & 445 \\
\hline & 11,91 & 149,7 & 301,0 & 448 \\
\hline & 11,90 & 149,3 & 301,0 & 422 \\
\hline \multirow{3}{*}{28 hari } & 12,28 & 150,0 & 301,0 & 475 \\
\hline & 12,16 & 149,0 & 301,7 & 470 \\
\hline & 12,13 & 150,0 & 301,7 & 490 \\
\hline
\end{tabular}

Sumber: Hasil pengujian laboratorium

Berdasarkan data Hasil kuat tekan diperoleh hasil bagi antara beban total sampai beton mengalami kehancuran dengan luas permukaan beton yang mengalami penekanan (Shen \& Xu, 2019). 


\subsection{Pengecoran dan Sambungan Beton}

Pengecoran yang baik adalah pengecoran yang dilakukan secara terus-menerus hingga selesainya suatu panel dan membentuk beton monolit. Namun ada kalanya pekerjaan pengecoran tidak langsung terselesaikan, sehingga diperlukan penyambungan beton. Penyambungan beton baru pada beton lama harus dilaksanakan secara tepat dan benar karena hal ini berpengaruh dalam kekuatan beton. Sambungan beton yang tidak dilakukan secara benar dapat mengakibatkan rusaknya struktur beton karena tidak bekerja secara maksimal.

Terdapat dua jenis sambungan, yaitu sambungan konstruksi dan sambungan gerak. Jenis sambungan yang digunakan pada penelitian ini termasuk jenis sambungan konstruksi. Sambungan konstruksi adalah suatu permukaan beton yang telah mengeras karena suatu batasan atau suatu keterlambatan dalam pengerjaanya, sehingga beton yang masih segar atau belum mengeras tidak dapat menyatu erat dengan beton yang telah mengeras. Penyambungan ini dipengaruhi beberapa faktor, yaitu ukuran sambungan, adanya penulangan dan water bar (penyekat air), sambungan horisontal atau vertikal, derajat penekanan, permukaan sambungan, dan derajat pengikatan. Salah satu hal penting yang juga mempengaruhi hasil dari sambungan ini adalah jeda (selang waktu) penyambungan antara beton lama dan beton baru.

Dalam pelaksanaan di lapangan umumnya sudut kemiringan permukaan sambungan kurang diperhatikan. Besarnya sudut kemiringan hanya tergantung pada kekentalan dari adukan beton. Tetapi sebenarnya salah satu faktor yang mempengaruhi kekuatan sambungan adalah sudut kemiringan dari permukaan sambungan itu sendiri. Sehingga dalam penelitian ini ditinjau 2 jenis sudut kemiringan penyambungan beton, yaitu sudut kemiringan $45^{\circ}$ dan $60^{\circ}$. Sebelum pengecoran beton baru dilakukan, permukaan beton lama yang akan disambung harus dibersihkan dan dibuat kasar terlebih dahulu seperti terlihat pada Gambar 1. Setelah itu pengecoran beton baru dilakukan setelah beton lama berumur 14 hari dan 28 hari seperti terlihat pada Gambar 2.
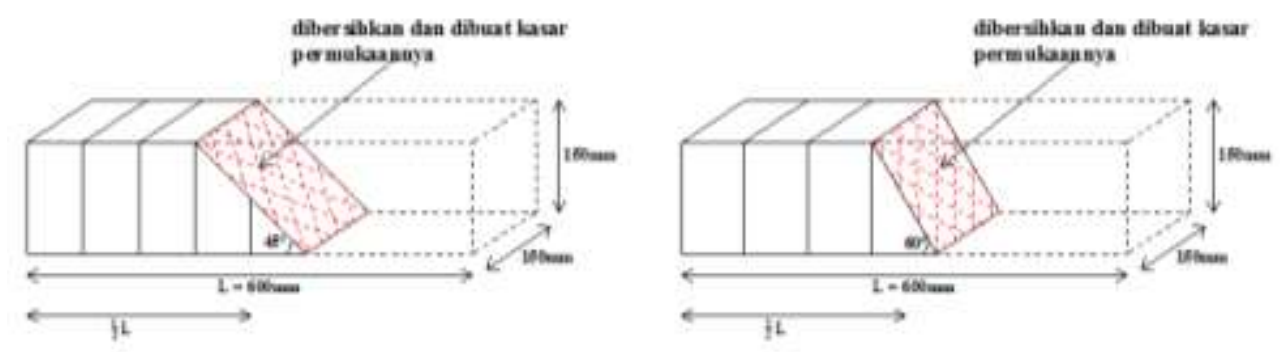

Gambar 1. Pengecoran Parsial
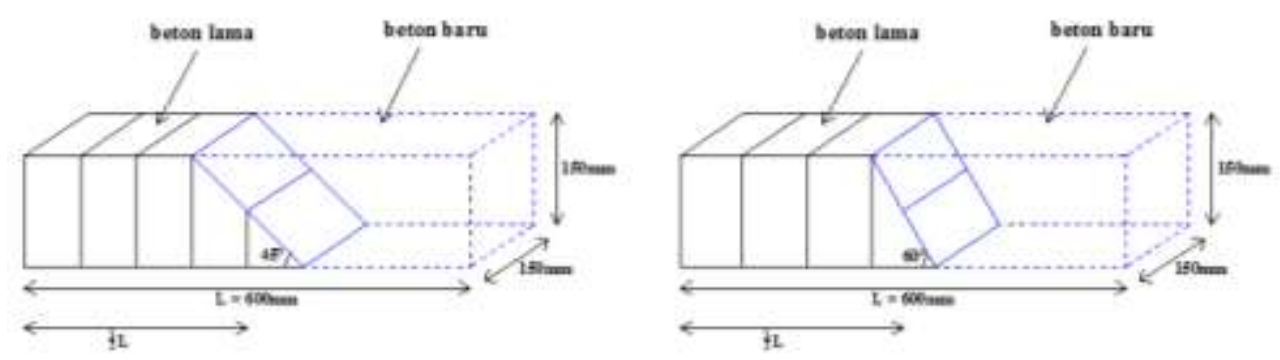

Gambar 2. Pengecoran Beton Baru

\subsection{Pengujian Kuat Lentur Beton}

Kuat lentur beton adalah kemampuan beton menahan tegangan lentur sampai terjadinya keruntuhan (Fládr \& Bílý, 2018). Salah satu kelemahan beton adalah ketidakmampuannya menahan gaya tarik, 
akibatnya beton tanpa tulangan akan mengalami retak-retak atau keruntuhan bila dibebani. Pengujian kuat lentur biasanya dilakukan dengan langkah-langkah seperti yang direkomendasikan ASTM (American Society for Testing and Materials) menggunakan balok dengan third-point loading (Annual Book of ASTM Standards Volume 04.02 Concrete and Aggregates, 2019). Posisi balok pada pengujian kuat lentur dapat dilihat pada Gambar 3.
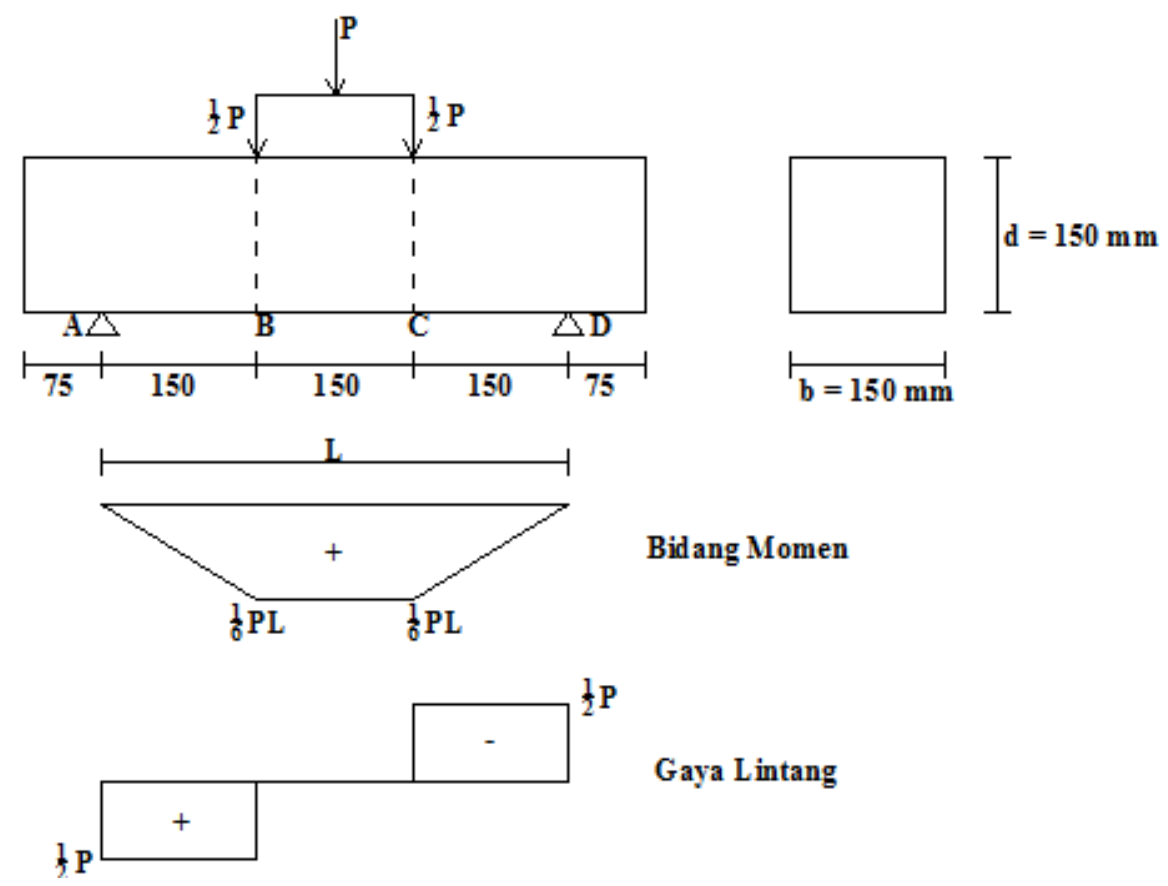

Gambar 3. Posisi balok pada pengujian kuat lentur

Berdasarkan ASTM C 78-84 tahun 1993, bentang pengujian diambil tiga kali dari penampang dan panjang balok diluar tumpuan minimum sebesar $25 \mathrm{~mm}$. Pada pengujian ini benda uji balok berukuran $150 \mathrm{~mm} \times 150 \mathrm{~mm} \times 600 \mathrm{~mm}$, maka bentang pengujian didapat $450 \mathrm{~mm}$, sehingga panjang balok di luar tumpuan menjadi $75 \mathrm{~mm}$ seperti terlihat pada Gambar 4.

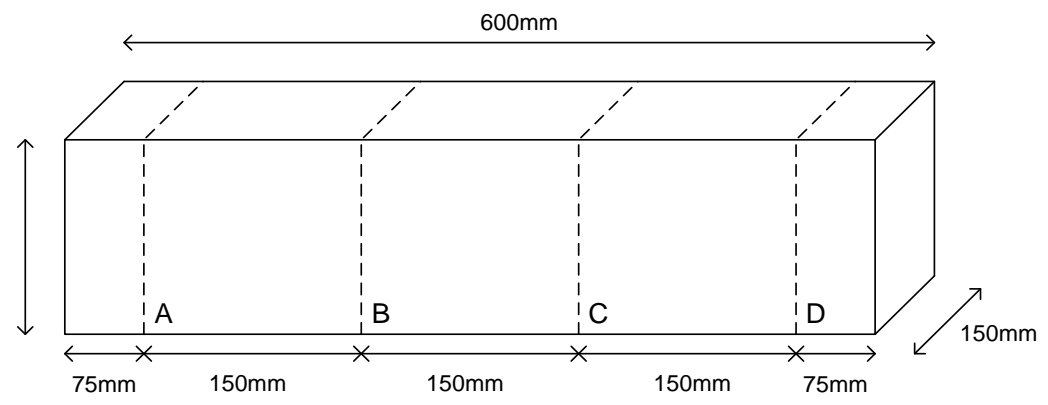

Gambar 4. Benda uji balok

Kuat lentur balok didapat dengan cara memberi beban pada balok perlahan-lahan sampai suatu saat balok terbelah dua atau retak. Pola retak yang terjadi pada balok umumnya berupa retak lentur dan retak geser. Pola retak tersebut untuk masing-masing balok berbeda. Hal ini disebabkan oleh penyaluran pembebanan dan karakteristik beton pada masing-masing balok tidak sama. Retak-retak awal berupa retak lentur yang terjadi pada sisi tarik daerah momen terbesar yaitu pada daerah tengah bentang balok didaerah antara dua titik beban. Retak lentur untuk semua balok terjadi di beberapa tempat dengan jumlah dan jarak retak berbeda untuk masing-masing balok. Retak lentur 
terjadi hampir tegak lurus terhadap sumbu balok (Standard Test Method for Flexural Strength of Concrete, 2018).

Retak geser pada balok ditandai dengan retak miring yang merupakan pertanda bahwa retak tarik diagonal mulai terjadi dan biasanya merupakan kelanjutan dari retak lentur. Kecepatan perubahan dari retak lentur awal menjadi retak lentur geser tergantung dari percepatan pertumbuhan dan tinggi dari retak lentur, di samping dari besarnya tegangan geser yang bekerja didekat ujung atas retak lentur.

Jarak titik belah balok sampai ujung balok sangat penting untuk menentukan rumus yang dipakai, yaitu:

1. Jika titik belah pada daerah B-C (retak akibat lentur), maka:

$$
\begin{aligned}
f_{r}= & \frac{M \cdot c}{I} \\
= & \frac{\frac{P . L}{6} \cdot \frac{1}{2} d}{\frac{1}{12} \cdot b \cdot d^{3}} \\
f_{r} & =\frac{P \cdot L}{b \cdot d^{2}}
\end{aligned}
$$

dimana,

$$
\begin{aligned}
& \mathrm{fr}=\text { Kuat lentur, } \mathrm{N} / \mathrm{mm} 2 \text { atau } \mathrm{MPa} \\
& \mathrm{P}=\text { Beban maksimum }, \mathrm{N} \\
& \mathrm{L}=\text { jarak } 2 \text { titik tumpuan, } \mathrm{mm} \\
& \mathrm{b}=\text { lebar balok, } \mathrm{mm} \\
& \mathrm{d}=\text { tinggi balok, } \mathrm{mm} \\
& \mathrm{M}=\text { momen yang bekerja pada balok, } \mathrm{N} . \mathrm{mm} \\
& \mathrm{c}=\text { jarak serat terluar ke garis netral, } \mathrm{mm} \\
& \mathrm{I}=\text { momen inersia penampang balok, } \mathrm{mm} 4
\end{aligned}
$$

2. Bila keruntuhan terjadi di luar bentang B-C dengan jarak tidak lebih dari 5\%.L yaitu balok retak akibat lentur dan geser, maka:

$$
\begin{aligned}
f_{r} & =\frac{M \cdot c}{I} \\
& =\frac{\frac{1}{2} P a \cdot \frac{1}{2} d}{\frac{1}{12} \cdot b \cdot d^{3}} \\
f_{r} & =\frac{3 \cdot P \cdot a}{b \cdot d^{2}}
\end{aligned}
$$

3. Bila keruntuhan terjadi diluar daerah B-C $+(5 \% . \mathrm{L})$, yaitu balok retak akibat geser, maka hasil pengujian tidak dapat dipergunakan. 
Untuk pengujian kuat lentur dalam penelitian ini dilakukan terhadap 3 jenis sambungan beton, yaitu beton tanpa sambungan, beton dengan sambungan tanpa bondcrete, dan beton dengan sambungan bondcrete. Pengujian kuat lentur dilakukan setelah beton berumur 28 hari. Untuk beton dengan sambungan, pengujian dilakukan setelah sambungan beton baru berumur 28 hari. Untuk tiap-tiap pengujian digunakan 3 buah benda uji. Hasil dari pengujian kuat lentur tersebut dapat dilihat pada Tabel 2.

Tabel 2. Data Hasil Uji Kuat Tekan Beton Tanpa Sambungan Pada Umur 28 Hari

\begin{tabular}{|c|c|c|c|}
\hline \multicolumn{2}{|c|}{ Jenis Benda Uji } & $\begin{array}{l}\text { Berat } \\
(\mathbf{k g})\end{array}$ & $\begin{array}{c}\text { Beban Hancur } \\
(\mathrm{kg})\end{array}$ \\
\hline \multirow{3}{*}{\multicolumn{2}{|c|}{ Tanpa Sambungan }} & 31,233 & 2550 \\
\hline & & 31,494 & 2900 \\
\hline & & 31,093 & 3030 \\
\hline \multirow{6}{*}{$\begin{array}{c}\text { Sambungan dengan } \\
\text { bondcrete } 45^{\circ}\end{array}$} & \multirow{3}{*}{$\begin{array}{l}\text { Umur beton } \\
14 \text { hari }\end{array}$} & 150,333 & 1950 \\
\hline & & 150,000 & 1810 \\
\hline & & 150,333 & 1900 \\
\hline & \multirow{3}{*}{$\begin{array}{l}\text { Umur beton } \\
28 \text { hari }\end{array}$} & 150,000 & 2850 \\
\hline & & 150,333 & 2270 \\
\hline & & 150,000 & 2090 \\
\hline \multirow{6}{*}{$\begin{array}{c}\text { Sambungan dengan } \\
\text { bondcrete } 60^{\circ}\end{array}$} & \multirow{3}{*}{$\begin{array}{l}\text { Umur beton } \\
14 \text { hari }\end{array}$} & 150,333 & 1990 \\
\hline & & 150,000 & 1820 \\
\hline & & 150,000 & 1290 \\
\hline & \multirow{3}{*}{$\begin{array}{l}\text { Umur beton } \\
28 \text { hari }\end{array}$} & 150,333 & 1890 \\
\hline & & 150,333 & 1850 \\
\hline & & 149,667 & 1750 \\
\hline \multirow{6}{*}{$\begin{array}{l}\text { Sambungan tanpa } \\
\text { bondcrete } 45^{\circ}\end{array}$} & \multirow{3}{*}{$\begin{array}{l}\text { Umur beton } \\
14 \text { hari }\end{array}$} & 150,000 & 2200 \\
\hline & & 150,333 & 1350 \\
\hline & & 150,333 & 1850 \\
\hline & \multirow{3}{*}{$\begin{array}{l}\text { Umur beton } \\
28 \text { hari }\end{array}$} & 150,000 & 1720 \\
\hline & & 150,000 & 2250 \\
\hline & & 150,333 & 2150 \\
\hline \multirow{6}{*}{$\begin{array}{l}\text { Sambungan tanpa } \\
\text { bondcrete } 60^{\circ}\end{array}$} & \multirow{3}{*}{$\begin{array}{l}\text { Umur beton } \\
14 \text { hari }\end{array}$} & 150,333 & 1650 \\
\hline & & 150,333 & 1550 \\
\hline & & 149,667 & 2000 \\
\hline & \multirow{3}{*}{$\begin{array}{l}\text { Umur beton } \\
28 \text { hari }\end{array}$} & 150,333 & 1150 \\
\hline & & 150,000 & 1650 \\
\hline & & 150,000 & 1000 \\
\hline
\end{tabular}

Sumber: Hasil pengujian laboratorium

\section{Hasil dan Pembahasan}

Hasil dari pengujian pada penelitian ini berupa hasil pengujian beton segar, pengujian kuat tekan beton, pengujian kuat lentur beton, dan pengaruh penyambungan beton dengan bondcrete terhadap kuat lentur beton.

\subsection{Pengujian Beton Segar}

Pengujian beton segar dilakukan pada beberapa jenis adukan. Untuk pengujian kuat tekan, dilakukan pengujian beton segar (slump test) untuk beton silinder. Sedangkan untuk pengujian kuat lentur, dilakukan pengujian untuk jenis adukan balok beton tanpa sambungan, sambungan beton dengan umur 14 hari, dan sambungan beton dengan umur 28 hari. Nilai slump rata-rata yang didapat dalam pengujian ini adalah $41,5 \mathrm{~mm}$, hasil ini memenuhi persyaratan nilai slump yaitu sebesar 30-60 mm berdasarkan SNI 03-2834-2000 tentang Tata Cara Pembuatan Rencana Campuran Beton Normal. Hasil pengukuran nilai slump secara lengkap dapat dilihat pada Tabel 3. 
Tabel 3. Hasil Pengujian Slump

\begin{tabular}{ccc}
\hline Jenis Adukan & $\begin{array}{c}\text { Nilai Slump } \\
(\mathbf{m m})\end{array}$ & $\begin{array}{c}\text { Nilai Slump } \\
\text { Rata-rata }(\mathbf{m m})\end{array}$ \\
\hline Beton silinder & 41 & \\
\cline { 1 - 2 } & \multirow{2}{*}{41,5} \\
\cline { 1 - 2 } Balok Beton tanpa sambungan & 40 & \\
\hline Sambungan beton yang berumur 14 hari & 40 & \\
\cline { 1 - 2 } Sambungan beton yang berumur 28 hari & 45 &
\end{tabular}

Sumber: Hasil pengujian laboratorium

\subsection{Pengujian Kuat Tekan Beton}

Campuran beton yang direncanakan dalam mix design dapat dikatakan benar jika kuat tekan karakteristik yang dihasilkan dari penelitian lebih besar atau sama besar dengan kuat tekan yang direncanakan semula. Pengujian kuat tekan beton dilakukan untuk memastikan bahwa mutu beton yang digunakan untuk pengujian kuat lentur beton sudah sesuai dengan mutu beton yang direncanakan, yaitu f'c $=25 \mathrm{Mpa}$. Nilai rata-rata kuat tekan beton pada umur 28 hari didapat sebesar 27,188 Mpa, hasil ini memenuhi kuat tekan yang direncanakan. Data hasil dari pengujian kuat tekan secara lengkap dapat dilihat pada Tabel 4.

Tabel 4. Data Hasil Uji Kuat Tekan Beton

\begin{tabular}{|c|c|c|c|c|}
\hline $\begin{array}{l}\text { Umur } \\
\text { Beton }\end{array}$ & $\begin{array}{c}\text { Diameter rata-rata } \\
(\mathrm{mm})\end{array}$ & $\begin{array}{c}\text { Beban Hancur } \\
(\mathbf{N})\end{array}$ & $\begin{array}{c}\text { Kuat Tekan } \\
\text { (MPa) }\end{array}$ & $\begin{array}{c}\text { Kuat Tekan rata-rata } \\
(\mathrm{MPa})\end{array}$ \\
\hline \multirow{3}{*}{7 hari } & 150,0 & 270000 & 15,279 & \multirow{3}{*}{15,233} \\
\hline & 150,0 & 260000 & 14,713 & \\
\hline & 149,3 & 275000 & 15,708 & \\
\hline \multirow{3}{*}{14 hari } & 149,0 & 390000 & 22,367 & \multirow{3}{*}{21,669} \\
\hline & 148,7 & 372000 & 21,421 & \\
\hline & 149,0 & 370000 & 21,220 & \\
\hline \multirow{3}{*}{21 hari } & 150,0 & 445000 & 25,182 & \multirow{3}{*}{24,913} \\
\hline & 149,7 & 448000 & 25,453 & \\
\hline & 149,3 & 422000 & 24,105 & \\
\hline \multirow{3}{*}{28 hari } & 150,0 & 475000 & 26,880 & \multirow{3}{*}{27,188} \\
\hline & 149,0 & 470000 & 26,955 & \\
\hline & 150,0 & 490000 & 27,728 & \\
\hline
\end{tabular}

Sumber: Hasil pengujian laboratorium

\subsection{Pengujian Kuat Lentur Beton}

Untuk pengujian kuat lentur ini dilakukan terhadap 3 macam jenis beton, yaitu beton tanpa sambungan, beton dengan sambungan tanpa bahan perekat, dan beton dengan sambungan yang diberi bondcrete sebagai bahan perekat.

\subsubsection{Beton Tanpa Sambungan}

Pengujian kuat lentur beton dilakukan pada hari ke-28. Untuk beton tanpa sambungan titik belahnya terjadi pada daerah $\mathrm{B}-\mathrm{C}$ dengan kuat lentur rata-rata sebesar 3,747 $\mathrm{MPa}$. Besarnya kuat lentur untuk balok beton tanpa sambungan dapat dilihat pada Tabel 5 .

Tabel 5. Kuat Lentur Beton Tanpa Sambungan

\begin{tabular}{ccccc}
\hline $\begin{array}{c}\text { Jenis Benda } \\
\text { Uji }\end{array}$ & $\begin{array}{c}\text { Berat } \\
(\mathbf{k g})\end{array}$ & $\begin{array}{c}\text { Beban Hancur } \\
(\mathbf{k g})\end{array}$ & $\begin{array}{c}\text { Kuat Lentur } \\
(\mathbf{M P a})\end{array}$ & $\begin{array}{c}\text { Kuat Lentur rata-rata } \\
(\mathbf{M P a})\end{array}$ \\
\hline \multirow{2}{*}{$\begin{array}{c}\text { Tanpa } \\
\text { Sambungan }\end{array}$} & 31,233 & 2550 & 3,340 & \\
\cline { 2 - 4 } & 31,494 & 2900 & 3,824 & \multirow{2}{*}{3,747} \\
\cline { 2 - 4 } & 31,093 & 3030 & 4,076 & \\
\hline
\end{tabular}

Sumber: Hasil pengujian laboratorium 


\subsubsection{Beton Dengan Sambungan Bondcrete}

Untuk beton dengan sambungan menggunakan bondcrete, terdapat 2 jenis umur penyambungan, yaitu penyambungan beton setelah beton lama berumur 14 dan 28 hari. Selain itu juga terdapat 2 jenis sudut sambungan, yaitu sudut $45^{\circ}$ dan $60^{\circ}$. Beton yang disambung menggunakan bondcrete titik belahnya terjadi pada daerah B - C dengan kuat lentur rata-rata untuk sambungan $45^{\circ}$ pada umur 14 hari sebesar $3,195 \mathrm{MPa}$, sambungan $45^{\circ}$ pada umur 28 hari sebesar 2,510 $\mathrm{MPa}$, sambungan $60^{\circ}$ pada umur 14 hari sebesar $2,432 \mathrm{MPa}$, dan sambungan $60^{\circ}$ pada umur 28 hari sebesar 2,264 MPa. Hasil perhitungan kuat lentur beton dengan sambungan menggunakan bondcrete secara lengkap dapat dilihat pada Tabel 6 .

Tabel 6. Kuat Lentur Beton Dengan Menggunakan Bondcrete

\begin{tabular}{|c|c|c|c|}
\hline Jenis Benda Uji & $\begin{array}{c}\text { Beban Hancur } \\
(\mathrm{kg})\end{array}$ & $\begin{array}{l}\text { Kuat Lentur } \\
(\mathrm{MPa})\end{array}$ & $\begin{array}{c}\text { Kuat Lentur } \\
\text { rata-rata (MPa) }\end{array}$ \\
\hline \multirow{3}{*}{$\begin{array}{c}\text { Sambungan } 45^{\circ} \text {, dengan } \\
\text { bondcrete, umur beton } 14 \text { hari }\end{array}$} & 2850 & 3,800 & \multirow{3}{*}{3,195} \\
\hline & 2270 & 2,993 & \\
\hline & 2090 & 2,793 & \\
\hline \multirow{3}{*}{$\begin{array}{c}\text { Sambungan } 45^{\circ} \text {, dengan } \\
\text { bondcrete, umur beton } 28 \text { hari }\end{array}$} & 1950 & 2,588 & \multirow{3}{*}{2,510} \\
\hline & 1810 & 2,419 & \\
\hline & 1900 & 2,522 & \\
\hline \multirow{3}{*}{$\begin{array}{c}\text { Sambungan } 60^{\circ} \text {, dengan } \\
\text { bondcrete, umur beton } 14 \text { hari }\end{array}$} & 1890 & 2,492 & \multirow{3}{*}{2,432} \\
\hline & 1850 & 2,456 & \\
\hline & 1750 & 2,349 & \\
\hline \multirow{3}{*}{$\begin{array}{c}\text { Sambungan } 60^{\circ} \text {, dengan } \\
\text { bondcrete, umur beton } 28 \text { hari }\end{array}$} & 1990 & 2,636 & \multirow{3}{*}{2,264} \\
\hline & 1820 & 2,438 & \\
\hline & 1290 & 1,720 & \\
\hline
\end{tabular}

Sumber: Hasil pengujian laboratorium

\subsubsection{Beton Tanpa Sambungan Bondcrete}

Untuk beton dengan sambungan tanpa menggunakan bondcrete terdapat 2 jenis umur penyambungan, yaitu penyambungan beton setelah beton lama berumur 14 dan 28 hari. Selain itu juga terdapat 2 jenis sudut sambungan, yaitu sudut $45^{\circ}$ dan $60^{\circ}$. Beton yang disambung tanpa menggunakan bondcrete titik belahnya terjadi pada daerah B $-\mathrm{C}$. Hasil perhitungan kuat lentur beton dengan sambungan tanpa menggunakan bondcrete secara lengkap dapat dilihat pada Tabel 7.

Tabel 7. Kuat Lentur Beton Dengan Sambungan Tanpa Menggunakan Bondcrete

\begin{tabular}{|c|c|c|c|}
\hline Jenis Benda Uji & $\begin{array}{c}\text { Beban Hancur } \\
\text { (kg) }\end{array}$ & $\begin{array}{l}\text { Kuat Lentur } \\
\text { (MPa) }\end{array}$ & $\begin{array}{c}\text { Kuat Lentur rata-rata } \\
(\mathrm{MPa})\end{array}$ \\
\hline \multirow{3}{*}{$\begin{array}{l}\text { Sambungan } 45^{\circ} \text {, tanpa } \\
\text { bondcrete, umur beton } 14 \text { hari }\end{array}$} & 1720 & 2,288 & \multirow{3}{*}{2,716} \\
\hline & 2250 & 3,007 & \\
\hline & 2150 & 2,854 & \\
\hline \multirow{3}{*}{$\begin{array}{l}\text { Sambungan } 45^{\circ} \text {, tanpa } \\
\text { bondcrete, umur beton } 28 \text { hari }\end{array}$} & 2200 & 2,933 & \multirow{3}{*}{2,396} \\
\hline & 1350 & 1,800 & \\
\hline & 1850 & 2,456 & \\
\hline \multirow{3}{*}{$\begin{array}{c}\text { Sambungan } 60^{\circ} \text {, tanpa } \\
\text { bondcrete, umur beton } 14 \text { hari }\end{array}$} & 1650 & 2,176 & \multirow{3}{*}{2,306} \\
\hline & 1550 & 2,058 & \\
\hline & 2000 & 2,685 & \\
\hline \multirow{3}{*}{$\begin{array}{l}\text { Sambungan } 60^{\circ} \text {, tanpa } \\
\text { bondcrete, umur beton } 28 \text { hari }\end{array}$} & 1150 & 1,527 & \multirow{3}{*}{1,684} \\
\hline & 1650 & 2,190 & \\
\hline & 1000 & 1,336 & \\
\hline
\end{tabular}

Sumber: Hasil pengujian laboratorium 
Hasil perhitungan kuat lentur rata-rata balok untuk semua jenis sambungan (balok beton tanpa sambungan, balok beton dengan sambungan tanpa bondcere, dan balok beton dengan sambungan menggunakan bondcrete) dapat dilihat pada Tabel 8. Untuk balok beton dengan sambungan tanpa bondcere dan balok beton dengan sambungan menggunakan bondcrete, terdapat 2 jenis umur penyambungan, yaitu penyambungan beton setelah beton lama berumur 14 dan 28 hari.

Tabel 8. Hasil Perhitungan Kuat Lentur Balok Tanpa Sambungan Dan Dengan Sambungan

\section{Jenis Benda Uji}

\section{Kuat Lentur rata-rata (MPa)}

\begin{tabular}{ccc}
\hline \multicolumn{2}{c}{ Tanpa Sambungan } & 3,747 \\
\hline Sambungan $45^{\circ}$, & Dengan Bondcrete & 3,195 \\
\cline { 2 - 3 } Umur Beton 14 hari & Tanpa Bondcrete & 2,716 \\
\hline Sambungan $45^{\circ}$, & Dengan Bondcrete & 2,510 \\
\cline { 2 - 3 } Umur Beton 28 hari & Tanpa Bondcrete & 2,396 \\
\hline Sambungan $60^{\circ}$, & Dengan Bondcrete & 2,432 \\
\cline { 2 - 3 } Umur Beton 14 hari & Tanpa Bondcrete & 2,306 \\
\hline Sambungan $60^{\circ}$, & Dengan Bondcrete & 2,264 \\
\cline { 2 - 3 } Umur Beton 28 hari & Tanpa Bondcrete & 1,684 \\
\hline Sumber: Hasil pengujian laboratorium &
\end{tabular}

Sumber: Hasil pengujian laboratorium

\subsection{Pengaruh penyambungan beton dengan bondcrete terhadap kuat lentur beton}

Pada penelitian ini diketahui bahwa bondcrete sebagai bahan perekat mampu menambah kekuatan lentur dari balok beton yang disambung. Dari hasil pengujian kuat lentur beton dihasilkan nilai kuat lentur yang lebih besar pada balok beton yang disambung menggunakan bondcrete dari pada yang tidak menggunakan bondcrete. Persentase peningkatan kekuatan lentur beton menggunakan bondcrete dapat dilihat pada Tabel 9.

Tabel 9. Persentase peningkatan kekuatan lentur beton menggunakan bondcrete setelah penyambungan

\begin{tabular}{|c|c|c|c|c|}
\hline \multicolumn{2}{|c|}{ Jenis Benda Uji } & $\begin{array}{l}\text { Kuat Lentur } \\
\text { rata-rata } \\
\text { (MPa) }\end{array}$ & $\begin{array}{c}\text { Peningkatan } \\
\text { Kuat Lentur } \\
(\%)\end{array}$ & $\begin{array}{c}\text { Peningkatan Kuat } \\
\text { Lentur rata-rata } \\
(\%)\end{array}$ \\
\hline \multirow{2}{*}{$\begin{array}{l}\text { Sambungan } 45^{\circ} \text {, } \\
\text { Umur Beton } 14 \text { hari }\end{array}$} & Tanpa Bondcrete & 2,716 & \multirow{2}{*}{17,638} & \multirow{8}{*}{15,572} \\
\hline & Dengan Bondcrete & 3,195 & & \\
\hline \multirow{2}{*}{$\begin{array}{l}\text { Sambungan } 45^{\circ}, \\
\text { Umur Beton } 28 \text { hari }\end{array}$} & Tanpa Bondcrete & 2,396 & \multirow{2}{*}{4,732} & \\
\hline & Dengan Bondcrete & 2,510 & & \\
\hline \multirow{2}{*}{$\begin{array}{l}\text { Sambungan } 60^{\circ}, \\
\text { Umur Beton } 14 \text { hari }\end{array}$} & Tanpa Bondcrete & 2,306 & \multirow{2}{*}{5,481} & \\
\hline & Dengan Bondcrete & 2,432 & & \\
\hline \multirow{2}{*}{$\begin{array}{l}\text { Sambungan } 60^{\circ} \text {, } \\
\text { Umur Beton } 28 \text { hari }\end{array}$} & Tanpa Bondcrete & 1,684 & \multirow{2}{*}{34,437} & \\
\hline & Dengan Bondcrete & 2,264 & & \\
\hline
\end{tabular}

Sumber: Hasil pengujian laboratorium

Dari Tabel 9 dapat dilihat bahwa kuat lentur balok beton yang menggunakan bondcrete rata-rata bertambah sebesar 15,572\% dari balok beton yang tidak menggunakan bondcrete. Meskipun kekuatannya bertambah, balok beton yang disambung menggunakan bondcrete kuat lenturnya belum mencapai kuat lentur dari balok yang tidak disambung yaitu sebesar 3,747 MPa.

\section{Kesimpulan}

Dari penelitian ini dapat pada pengujian kuat tekan yang dilakukan, didapatkan mutu beton memenuhi mutu beton yang direncanakan yaitu sebesar 27,188 MPa. Selain itu 
semakin bertambahnya umur beton lama saat penyambungan akan menghasilkan nilai kuat lentur beton yang semakin kecil. Dari beberapa variasi pengujian sudut kemiringan sambungan beton, dapat disimpulkan bahwa eton beton yang disambung dengan sudut kemiringan penyambungan $45^{\circ}$ menghasilkan nilai kuat lentur yang lebih besar daripada beton yang disambung dengan sudut kemiringan penyambungan $60^{\circ}$. Penggunaan bondcrete sebagai perekat beton lama dan beton baru dapat menambah kekuatan lentur balok beton sebesar 15,572\%, penggunaan bondcrete tersebut cukup efektif untuk menambah kekuatan lentur balok beton.

Dalam Pekerjaan konstruksi dilapangan terutama pada pekerjaan beton, diharapkan pengecoran dilakukan sekaligus sampai seluruh bagian selesai dikerjakan. Jika harus dilakukan penyambungan beton, diperlukan perhitungan yang sangat teliti agar tidak terjadi penurunan kuat lentur yang terlalu besar. Selang waktu pengecoran beton lama dengan beton baru seharusnya tidak terlalu lama agar beton tetap monolit. Sudut kemiringan penyambungan $45^{\circ}$ merupakan sudut yang paling efektif. Penggunaan bahan perekat beton seperti bondcrete juga sangat dianjurkan untuk menambah kekuatan lentur dari balok beton tersebut.

\section{Daftar Pustaka}

American Society for Testing and Materials (ASTM). Standard Test Method for Flexural Strength of Concrete, (2018).

American Society for Testing and Materials (ASTM). Annual Book of ASTM Standards Volume 04.02 Concrete and Aggregates, (2019).

Standar Nasional Indonesia (SNI) 03-2834-2000. Tata cara pembuatan rencana campuran beton normal, (2000).

Standar Nasional Indonesia (SNI) 1972:2008. Cara uji slump beton, (2008).

Fládr, J., \& Bílý, P. (2018). Specimen size effect on compressive and flexural strength of highstrength fibre-reinforced concrete containing coarse aggregate. Composites Part B: Engineering, 138, 77-86. https://doi.org/https://doi.org/10.1016/j.compositesb.2017.11.032

Hajek, P. (2017). Concrete Structures for Sustainability in a Changing World. Procedia Engineering, 171, 207-214. https://doi.org/https://doi.org/10.1016/j.proeng.2017.01.328

Nguyen, T. T., Goodier, C. I., \& Austin, S. A. (2020). Factors affecting the slump and strength development of geopolymer concrete. Construction and Building Materials, 261, 119945. https://doi.org/https://doi.org/10.1016/j.conbuildmat.2020.119945

Septiawan, R. (2014). Studi Penelitian Pengaruh Letak Sambungan Cor Beton Terhadap Uji Kuat Lentur Pada Balok Beton Bertulang. Jurnal Kajian Pendidikan Teknik Bangunan, 1(1), 1-8.

Shen, J., \& Xu, Q. (2019). Effect of elevated temperatures on compressive strength of concrete. Construction and Building Materials, 229, 116846. https://doi.org/https://doi.org/10.1016/j.conbuildmat.2019.116846

Velay-Lizancos, M., Martinez-Lage, I., Azenha, M., Granja, J., \& Vazquez-Burgo, P. (2018). Concrete with fine and coarse recycled aggregates: E-modulus evolution, compressive strength and non-destructive testing at early ages. Construction and Building Materials, 193, 323-331. https://doi.org/https://doi.org/10.1016/j.conbuildmat.2018.10.209 
Zulkarnain, F. (2018). Development of k-300 concrete mix for earthquake-resistant Housing infrastructure in indonesia. Journal of Physics: Conference Series, 970, 12001. https://doi.org/10.1088/1742-6596/970/1/012001 